\title{
Clay content drives carbon stocks in soils under a plantation of Eucalyptus saligna Labill. in southern Brazil
}

\author{
Tanise Luisa Sausen ${ }^{1,5}$, Guilherme Frederico de Paula Schaefer ${ }^{2}$, Michely Tomazi ${ }^{3}$,
} Lívia Scheunemann dos Santos ${ }^{4}$, Cimélio Bayer ${ }^{2}$ and Luís Mauro Gonçalves Rosa ${ }^{2}$

Received: 12 December, 2012. Accepted: 25 November, 2013

\begin{abstract}
Soil carbon accumulation is largely dependent on net primary productivity. To our knowledge, there have been no studies investigating the dynamics of carbon accumulation in weathered subtropical soils, especially in managed eucalyptus plantations. We quantified the seasonal input of leaf litter, the leaf decomposition rate and soil carbon stocks in an commercial plantation of Eucalyptus saligna Labill. in southern Brazil. Our goal was to evaluate, through multiple linear regression, the influence that certain chemical characteristics of litter, as well as chemical and physical characteristics of soil, have on carbon accumulation in soil organic matter fractions. Variables related to the chemical composition of litter were not associated with the soil carbon stock in the particulate and mineral fractions. However, certain soil characteristics were significantly associated with the carbon stock in both fractions. The concentrations of nutrients associated with plant growth and productivity, such as phosphorus, sulfur, copper and zinc, were associated with variations in the labile carbon pool (particulate fraction). Clay content was strongly associated with the carbon stock in the mineral fraction. The carbon accumulation and stabilization in weathered subtropical Ultisol seems to be mainly associated with the intrinsic characteristics of the soil, particularly clay content, rather than with the quantity, chemical composition or decomposition rate of the litter.
\end{abstract}

Key words: weathered soils, decomposition, soil organic matter fractions, litter input

\section{Introduction}

The main source of soil organic matter (SOM) is the carbon dioxide fixed by photosynthesis and incorporated into the SOM fraction through the decomposition of leaves, stems and roots. The composition of plant tissues is a major factor influencing the process of their decomposition and soil carbon incorporation in temperate ecosystems (Kögel-Knabner 2002; Kleber et al. 2007). The soil organic carbon may reside in more labile or stable organic matter according to the chemical composition and recalcitrance of plant residues (Berg \& McClaugherty 2008). Organic compounds with a high rate of decomposition, mainly soluble carbohydrates, represent pools of organic matter that are more labile, whereas lipids, waxes and lignin have a slower rate of decomposition and are considered compounds that are more stable or recalcitrant.

The differentiation of soil organic carbon into labile carbon (defined by its residence time of months to years) and recalcitrant carbon (with a residence time of decades to hundreds of years) can improve understanding of the mechanisms associated with the stability of carbon in soil. The granulometric fractionation of soil is a methodology that can be used to differentiate and quantify labile and recalcitrant pools of SOM (Cambardella \& Elliot 1992, Bayer

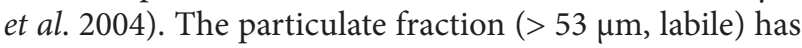
a composition comparable to that of plant material in the initial phase of decomposition. The mineral fraction $(<53$ $\mu \mathrm{m}$, stable) includes organic molecules that exhibit strong interactions with minerals in the silt and clay fractions in a more advanced stage of humification (Christensen 2001; Six et al. 2001).

In addition to the influence that the chemical composition of plant residues has on the process of decomposition and incorporation of SOM, Morris et al. (2007) showed that soil characteristics have a strong influence on the dynamics of carbon accumulation. Those authors found that the availability of calcium and nitrogen were strongly associated

\footnotetext{
${ }^{1}$ Universidade Regional Integrada do Alto Uruguai e das Missões, Departamento de Ciências Biológicas, Laboratório de Sistemática e Ecologia Vegetal, Erechim, RS, Brazil

${ }^{2}$ Universidade Federal do Rio Grande do Sul, Faculdade de Agronomia, Porto Alegre, RS, Brazil

${ }^{3}$ Empresa Brasileira de Pesquisa Agropecuária, Dourados, MS, Brazil

${ }^{4}$ Universidade Federal do Rio Grande do Sul, Instituto de Biociências, Departamento de Botânica, Porto Alegre, RS, Brazil

${ }^{5}$ Author for correspondence: tasausen@uricer.edu.br
} 
with higher carbon storage in soil. Studies have supported the idea that the concentration of cations is important for the stabilization of SOM, especially in soils of temperate regions that have high levels of these ions (Clough \& Skjemstad 2000). However, in most weathered soils, which are characteristic of southern Brazil, the stabilization of SOM occurs through interaction with mineral surfaces and metal ions via ligand exchange or by establishing weak interactions, such as Van der Waals interactions or $\mathrm{H}$ bonding (Lützow et al. 2006). In addition, the availability of nitrogen might be related to increases or decreases in SOM decomposition rates (Fog 1988; Hobbie 2000).

The relationships among the chemical composition of plants, soil characteristics and soil carbon accumulation in forest plantations of eucalyptus have not been investigated, and the elucidation of the mechanisms associated with the soil carbon accumulation is important for understanding the dynamics of organic matter in weathered soils in the southern region of Brazil. The objectives of this study were to investigate the relationship between soil characteristics and carbon accumulation in SOM fractions; to determine the influence that the chemical composition of leaf litter has on carbon accumulation in SOM fractions; and to analyze the process of decomposition of the leaves of Eucalyptus saligna Labill. (Myrtaceae), especially the relationship between lignin concentration and soil carbon stocks.

\section{Material and methods}

\section{Study site and experimental design}

The study was conducted in a commercial eucalyptus plantation, operated by the Brazilian company Celulose Riograndense, within the "Terra Dura" zone of the city of Eldorado do Sul (51 $\left.35^{\prime} 38.43^{\prime \prime} \mathrm{W} ; 30^{\circ} 10^{\prime} 51.04^{\prime} \mathrm{S}\right)$, in the state of Rio Grande do Sul, Brazil. According to the Köppen classification system, the climate of the region is type Cfa (humid subtropical). The mean \pm standard deviation (SD) annual rainfall during the experimental period was $1891 \pm 93.5 \mathrm{~mm}$, and the mean monthly temperature was $18.2 \pm 4.5^{\circ} \mathrm{C}$. The soil in the area is an Ultisol, with an average composition of $50 \%$ sand, $10 \%$ silt and $40 \%$ clay, as evaluated at two soil depths $(0-25 \mathrm{~cm}$ and $25-50 \mathrm{~cm})$. The chemical characteristics and soil $\mathrm{pH}$ at both soil depths were evaluated according to the methodology proposed by Tedesco et al. (1995) and are presented in Tab. 1.

Soil and plant measurements were conducted in an area devoted to monoculture of Eucalyptus saligna Labill. (Clone 4039). At the time of the study, the E. saligna individuals in the area were three years old, halfway through the cycle in the second rotation. There were 1666 trees per hectare, with a spacing of $4 \times 1.5 \mathrm{~m}$ between individuals. In the study area, we delineated a transect of $1500 \mathrm{~m}^{2}$ and established six $10 \times 10 \mathrm{~m}$ plots, distributed along the transect, $10 \mathrm{~m}$ apart. During establishment of the trees, the soil of the area had been prepared with a nitrogen-phosphorus-potassium top dressing (15-0.7-30; $200 \mathrm{~g} /$ plant). In each experimental plot, we collected samples of soil and leaf litter for subsequent chemical analysis. Data were collected between May 2009 and June 2010.

\section{Quantification of total soil organic carbon and soil carbon fractions}

Using an graduated auger, we collected individual soil samples at five different locations within each plot and homogenized those into composite samples for each of the two depths evaluated. From each composite sample, three subsamples were taken for analysis of total organic carbon (TOC), as well as the fractions of particulate organic carbon (POC) and mineral carbon. The TOC was determined with a carbon analyzer (TOC-V; Shimadzu Scientific Instruments, Columbia, MD, USA), and the fractions were obtained by the granulometric fractionation method proposed by Cambardella \& Elliot (1992).

Soil sub-samples were initially dried at $50^{\circ} \mathrm{C}$, sieved through a $2-\mathrm{mm}$ mesh sieve and subjected to quantification of TOC and POC. In brief, $20 \mathrm{~g}$ of soil from each subsample were added to $60 \mathrm{ml}$ of sodium hexametaphosphate $(5 \mathrm{~g}$ $\mathrm{L}^{-1}$ ) and agitated for $15 \mathrm{~h}$ in 100-ml snap-cap flasks. The soil suspension obtained was passed through a $53-\mu$ m mesh sieve with the aid of a water jet. The material retained on the sieve, regarded as the POC fraction, was dried at $50^{\circ} \mathrm{C}$. After each sample had dried, we determined its mass and ground it in a mortar for later determination of organic carbon in the Shimadzu carbon analyzer. The content of mineral-associated carbon (MAC) was calculated as the difference between the POC and TOC.

The total stock of organic carbon and carbon stocks in the fractions were calculated using the following equation:

$$
\text { Stock }=C_{\text {organic }}{ }^{*} B D^{\star} L^{\star} 10
$$

where Stock is the stock of organic carbon $\left(\mathrm{mg} \mathrm{ha}^{-1}\right), C_{\text {organic }}$ is the concentration of organic carbon $\left(\mathrm{g} \mathrm{kg}^{-1}\right.$ soil), $B D$ is the bulk density of the soil $\left(\mathrm{g} \mathrm{cm}^{-3}\right)$, and $L$ is the layer thickness $(\mathrm{cm})$. Bulk density was determined with volumetric metal rings, as described by Pauletto (1997).

\section{Seasonal litter production}

Litter samples were collected monthly in $0.25-\mathrm{m}^{2}$ collectors $(0.50 \times 0.50 \mathrm{~m})$ that were $15-\mathrm{cm}$ deep with a bottom screen of fine nylon mesh. In each experimental plot, we distributed four litter collectors under the trees in May 2009. The samples were collected monthly between May 2009 and June 2010 (12 monthly collections). After each collection, the litter collectors were placed back into their original positions under the trees. Each month, the material collected each month was dried in an oven at $50^{\circ} \mathrm{C}$ for $24 \mathrm{~h}$, 
Table 1. Chemical characteristics and $\mathrm{pH}$ of the soil, at two different depths, under a commercial plantation of three-year-old individuals of Eucalyptus saligna Labill. (Clone 4039), within the city of Eldorado do Sul, in the state of Rio Grande do Sul, Brazil.

\begin{tabular}{|c|c|c|}
\hline \multirow{3}{*}{ Soil characteristic } & \multicolumn{2}{|c|}{ Depth } \\
\hline & $0-25 \mathrm{~cm}$ & $25-50 \mathrm{~cm}$ \\
\hline & $(\mathrm{n}=18)$ & $(\mathrm{n}=18)$ \\
\hline pH (SE) & $4.72(0.02)$ & $4.58(0.02)^{\star}$ \\
\hline $\mathrm{N}, \%(\mathrm{SE})$ & $0.09(0.00)$ & $0.08(0.00)^{*}$ \\
\hline $\mathrm{P}, \mathrm{mg} \mathrm{dm}^{-3}$ (SE) & $4.46(0.71)$ & $2.56(0.33)^{*}$ \\
\hline $\mathrm{K}, \mathrm{mg} \mathrm{dm}^{-3}(\mathrm{SE})$ & $57.11(4.74)$ & $56.39(4.90)$ \\
\hline $\mathrm{Al}, \mathrm{cmolc} \mathrm{dm}^{-3}$ (SE) & $1.93(0.14)$ & $3.05(0.10)^{*}$ \\
\hline $\mathrm{Ca}_{\text {troc }}, \mathrm{cmolc} \mathrm{dm}^{-3}$ (SE) & $1.78(0.16)$ & $0.91(0.07)^{*}$ \\
\hline $\mathrm{Mg}_{\text {troce }}, \mathrm{cmolc} \mathrm{dm}^{-3}(\mathrm{SE})$ & $0.79(0.07)$ & $0.53(0.03)^{\star}$ \\
\hline $\mathrm{Ca} / \mathrm{Mg}, \mathrm{cmolc} \mathrm{dm}^{-3}(\mathrm{SE})$ & $2.56(0.36)$ & $1.75(0.11)$ \\
\hline $\mathrm{Fe}, \mathrm{mg} \mathrm{kg}^{-1}(\mathrm{SE})$ & $79.2(2.85)$ & $89.6(4.18)^{\star}$ \\
\hline $\mathrm{S}, \mathrm{mg} \mathrm{dm}^{-3}(\mathrm{SE})$ & $5.42(0.34)$ & $4.02(0.36)^{*}$ \\
\hline $\mathrm{Cu}, \mathrm{mg} \mathrm{dm}^{-3}(\mathrm{SE})$ & $0.59(0.04)$ & $0.54(0.03)$ \\
\hline $\mathrm{B}, \mathrm{mg} \mathrm{dm}^{-3}(\mathrm{SE})$ & $0.61(0.03)$ & $0.63(0.04)$ \\
\hline $\mathrm{Zn}, \mathrm{mg} \mathrm{dm}{ }^{-3}$ (SE) & $0.52(0.04)$ & $0.32(0.03)^{*}$ \\
\hline $\mathrm{Mn}, \mathrm{mg} \mathrm{dm}^{-3}$ (SE) & $6.83(0.75)$ & $2.67(0.33)^{*}$ \\
\hline
\end{tabular}

$\mathrm{SE}$ - standard error; $\mathrm{N}$ - nitrogen; $\mathrm{P}$ - phosphorus; $\mathrm{K}$ - potassium; $\mathrm{Al}$ - aluminum; $\mathrm{Ca}_{\text {troc }}-$ exchangeable calcium; $\mathrm{Mg}_{\text {troc }}-$ exchangeable magnesium; $\mathrm{Fe}$ - iron; $\mathrm{S}$ - sulfur; $\mathrm{Cu}$ - copper; B - boron; $\mathrm{Zn}$ - zinc; $\mathrm{Mn}$ - manganese.

*Significant difference between soil depths according to Tukey's test $(p \leq 0.05)$.

after which it was manually separated into three fractions: leaves, twigs and bark. After screening, each fraction was again dried in an oven at $60^{\circ} \mathrm{C}$ to a constant weight and then weighed. The fractions of leaf litter produced during the winter, spring, summer and autumn were calculated as the sums of the monthly inputs, by season: winter (June, July and August); spring (September, October and November); summer (December, January and February); and autumn (March, April and May). The mean seasonal production of leaf litter mass was expressed in $\mathrm{tha}^{-1}$.

\section{Nutrients and carbon concentration in leaf litter}

The seasonal concentrations of carbon and nutrients were analyzed in the spring and autumn leaf litter fractions, which proved to be contrasting in terms of litter mass and leaf phenology. Samples of the leaf litter were dried at $60^{\circ} \mathrm{C}$ and macerated, after which $\approx 2 \mathrm{~g}$ were taken in order to quantify the concentration of carbon in the Shimadzu carbon analyzer (in $\mathrm{mg} \mathrm{ha}^{-1}$ ). For the nutrient analysis, $5 \mathrm{~g}$ of each sample were sent to the Soil Analysis Laboratory of the Federal University of Rio Grande do Sul School of Agronomy. The concentrations of leaf litter nutrients were assessed according to the methodology proposed by Tedesco et al. (1995) and expressed as $\mathrm{g} \mathrm{kg}^{-1}$ or $\mathrm{mg} \mathrm{kg} \mathrm{kg}^{-1}$.

\section{Leaf litter decomposition rate}

The leaf litter decomposition rate was determined by the litter-bag method (Berg et al. 1993). In May 2009, recently fallen senescent leaves were collected, dried at $60^{\circ} \mathrm{C}$, weighed and placed into $25 \times 25 \mathrm{~cm}$ nylon litter bags. A total of 72 litter bags, each containing $5 \mathrm{~g}$ of dried senescent leaves, were buried in the soil near the litter collectors distributed in each of the six plots (six litter bags per plot). On day 0 , as well as at months 1,2, 4, 6 and 12, one litter bag was collected from each plot and weighed. The leaf decomposition rate was expressed as the percentage of mass that remained in the litter bags in relation to initial mass. We determined the decomposition constant using the litter-bag decomposition data and the formula devised by Olson (1963):

$$
M_{t}=M_{0} e^{-k t}
$$

where $M_{t}$ is the mass remaining at time $t, M_{0}$ is the initial mass, e is the exponential constant, and $k$ is the decomposition constant. The carbon concentration was analyzed in the Shimadzu carbon analyzer on day 0 and at month 12 .

\section{Leaf and leaf litter lignin content}

The concentration of lignin was analyzed in the leaf litter fraction produced during the spring and autumn and in the litter bags on day 0 and at month 12 . Samples of the leaf litter fraction and litter bags $(0.05 \mathrm{~g})$ were homogenized in $50 \mathrm{mM}$ potassium phosphate buffer $(1.2 \mathrm{ml}, \mathrm{pH} 7.0)$ with a mortar and pestle and transferred to an Eppendorf tube (Ferrarese et al. 2002). The pellet was centrifuged $(1400 \times g, 4 \mathrm{~min})$ and washed by successive stirring and centrifugation as follows: twice with phosphate buffer $\mathrm{pH}$ 7.0 (1.2 ml); thrice with $1 \%(\mathrm{v} / \mathrm{v})$ Triton $^{\circ} \mathrm{X}-100$ in $\mathrm{pH} 7.0$ buffer $(1.2 \mathrm{ml})$; twice with $1 \mathrm{M} \mathrm{NaCl}$ in $\mathrm{pH} 7.0$ buffer $(1.2$ $\mathrm{ml})$; twice with distilled water $(1.2 \mathrm{ml})$; and twice with acetone $(800 \mu \mathrm{l})$. The pellet was dried in an oven $\left(60^{\circ} \mathrm{C}, 24\right.$ $\mathrm{h}$ ) and cooled in a vacuum desiccator. The dry matter was defined as the protein-free cell wall fraction. The reaction mixture $(200 \mu \mathrm{l}$ of thioglycolic acid plus $1 \mathrm{ml}$ of $2 \mathrm{M} \mathrm{HCl})$ was then added to the Eppendorf tube and heated $\left(95^{\circ} \mathrm{C}\right.$, $4 \mathrm{~h}$ ). After cooling at room temperature, the sample was centrifuged $(1400 \times g, 5 \mathrm{~min})$ and the supernatant was discarded. The pellet contained the lignin-thioglycolic acid (LTGA) complex. The pellet was washed three times with distilled water $(1.2 \mathrm{ml})$, and the LTGA was extracted by shaking $\left(30^{\circ} \mathrm{C}, 18 \mathrm{~h}, 160\right.$ oscillations $\left./ \mathrm{min}\right)$ in $0.5 \mathrm{M}$ $\mathrm{NaOH}(1 \mathrm{ml})$. After centrifugation $(1400 \times g, 5 \mathrm{~min})$, the supernatant was stored. The pellet was washed again with $0.5 \mathrm{M} \mathrm{NaOH}(500 \mu \mathrm{l})$ and mixed with the supernatant obtained earlier. The combined alkali extracts were acidified with concentrated $\mathrm{HCl}(300 \mu \mathrm{l})$. After precipitation $\left(0^{\circ} \mathrm{C}\right.$, $4 \mathrm{~h})$, the LTGA was recovered by centrifugation $(1,400$ $\times g, 10 \mathrm{~min}$ ) and washed two times with distilled water $(7 \mathrm{ml})$. The pellet was dried at $60^{\circ} \mathrm{C}$, dissolved in $0.5 \mathrm{M}$ 
$\mathrm{NaOH}$ and diluted to yield an appropriate absorbance for spectrophotometric determination at $280 \mathrm{~nm}$. Lignin was expressed as mg LTGA/g of dry weight.

\section{Relationship between soil characteristics, leaf litter characteristics and soil carbon concentration}

The nonparametric Kruskal-Wallis test was used initially to select a set of soil granulometric characteristics (clay content, sand content, silt content and $\mathrm{pH}$ ) and chemical characteristics (nitrogen, phosphorus, potassium, calcium, magnesium, aluminum, sulfur, zinc, copper, manganese) that would be most closely associated with spatial variations in the soil characteristics in the study area. The variables selected by the Kruskal-Wallis test were clay content, $\mathrm{pH}$, potassium, phosphorus, aluminum, calcium, magnesium, the calcium:magnesium ratio, sulfur, zinc and copper. To analyze those variables, we used multiple regression for the two dependent variables (carbon stock in the POC and MAC fractions), in an attempt to establish the contribution of each independent variable to explaining the variability in soil carbon concentration. Data were analyzed with the Statistical Package for the Social Sciences (SPSS Inc., Chicago, IL, USA), and values of $p \leq 0.1$ were considered significant. The relationships between the independent variables (leaf nutrient concentration, lignin concentration, the carbon:nitrogen ratio and the lignin:nitrogen ratio in the leaf litter fraction) and the dependent variables (concentrations of the POC and MAC fractions) were also determined through multiple linear regression with SPSS, also at a level of significance of $p \leq 0.1$.

\section{Soil and litter differences}

We used Tukey's test to analyze the differences between the two soil depths, in terms of the soil carbon stock, as well as the chemical and physical characteristics of the soil; the differences between the seasons, in terms of the chemical characteristics of the leaf litter; and the differences among the decomposition times, in terms of the mass of the litter bags. Analyses were again performed with SPSS, and the level of significance was set at $p \leq 0.05$.

\section{Results}

\section{Soil and litter}

The soil carbon stock had a higher proportion of MAC ( $80-92 \%$ of the TOC) than of POC (8-20\% of TOC). In the $\mathrm{MAC}$ and $\mathrm{POC}$ fractions, the soil carbon concentration was significantly higher in the samples for the $0-25 \mathrm{~cm}$ depth than in those for the 25-50 cm depth (Fig. 1). As can be seen in Fig. 2, the mean seasonal leaf litter production was similar among winter, spring and summer $\left(1.5-2.6 \mathrm{t} \mathrm{ha}^{-1}\right)$, whereas it was significantly lower in the autumn $\left(1.2 \mathrm{t} \mathrm{ha}^{-1}\right)$.

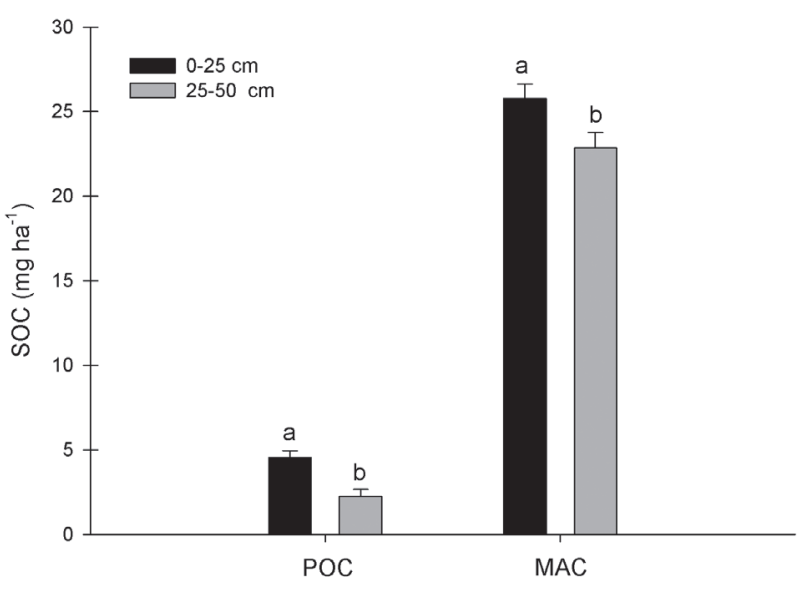

Figure 1. Soil organic carbon (SOC) stock in different soil organic matter fractions - particulate organic carbon (POC) and mineral-associated carbon (MAC) - under a commercial plantation of three-year-old individuals of Eucalyptus saligna Labill. (Clone 4039), within the city of Eldorado do Sul, in the state of Rio Grande do Sul, Brazil.

Different letters indicate significant differences $(p \leq 0.05)$ between depths (n $=18$ ).

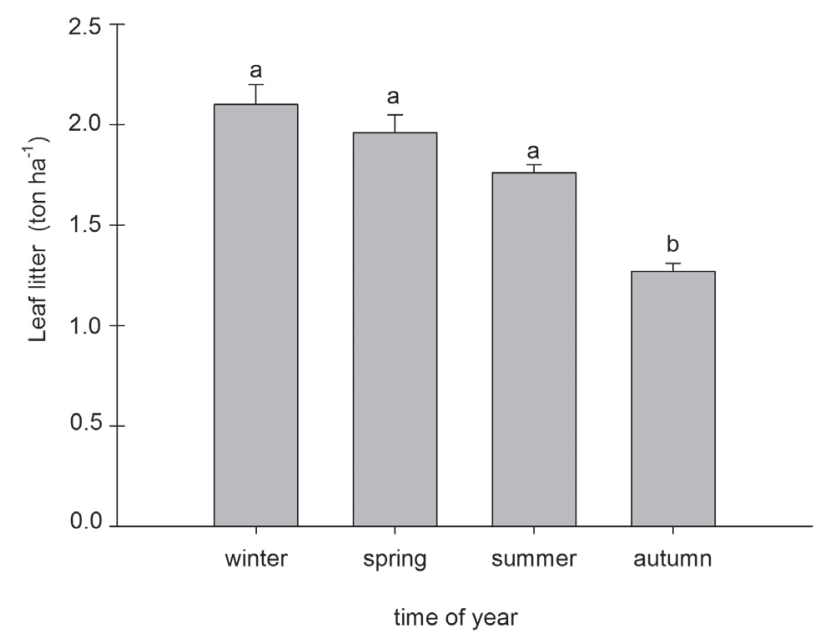

Figure 2. Seasonal production of leaf litter fraction in a commercial plantation of three-year-old individuals of Eucalyptus saligna Labill. (Clone 4039), within the city of Eldorado do Sul, in the state of Rio Grande do Sul, Brazil.

Different letters indicate significant differences $(p \leq 0.05)$ between depths $(n=18)$.

Because the greatest contrast, in terms of leaf litter mass, was between spring and autumn, we compared those two seasons in order to identify any differences in the concentrations of carbon and nutrients in the leaf litter fraction. We found a significant difference between spring and autumn in terms of the mean concentration of carbon in the leaf litter ( 0.96 vs. $0.65 \mathrm{mg} \mathrm{ha}^{-1}, p<0.001$ ), as well as the percentage of carbon in the leaves (Tab. 2). The chemical composition of the leaf litter produced in the spring showed significant differences in comparison with that of the leaf litter produced in the autumn: for lignin $(p=0.05)$; for phosphorus $(p<0.001)$; for potassium $(p<0.001)$; for calcium $(p<0.001)$; 
for iron ( $p=0.043$ ); for manganese $(p<0.001)$; and for boron $(p<0.001)$. The other macronutrients and micronutrients evaluated did not differ significantly different between the two seasons (Tab. 2).

\section{Leaf decomposition}

In relation to the initial mass, there was an mean reduction of $38.2 \%$ in the mass of the Eucalyptus saligna leaves after 12 months of evaluation. . The litter-bag mass was significantly lower after 4, 6 and 12 months of decomposition than on day 0 (Fig. 3). The decay constant, expressed as mean \pm standard error, was $0.49 \pm 0.027$. The most rapid reduction in litter-bag mass was observed in the first 30 days of assessment $\left(0.017 \mathrm{~g} \mathrm{day}^{-1}\right)$, despite the absence of a significant difference between day 0 and month 1 (day 30 ) in the litter bag mass. After 6 months (180 days) and 12 months (365 days), the mass reduction rate was $0.0058 \mathrm{~g} \mathrm{day}^{-1}$ and $0.0053 \mathrm{~g} \mathrm{day}^{-1}$, respectively. The carbon concentration in the litter bags after 12 months was significantly lower than that observed on day 0 by an average of $5 \%$, corresponding to a reduction rate of $\approx 0.25 \mathrm{~g} \mathrm{yr}^{-1}$. The lignin concentration in the litter bags after 12 months of decomposition showed a mean annual reduction of $0.94 \mu \mathrm{g} \mathrm{m}^{-1}$.

Table 2. Comparison between spring and autumn for macronutrients, micronutrients, carbon and lignin concentration in the leaf litter fraction in a commercial plantation of three-year-old individuals of Eucalyptus saligna Labill. (Clone 4039), within the city of Eldorado do Sul, in the state of Rio Grande do Sul, Brazil.

\begin{tabular}{|c|c|c|}
\hline Parameter & Spring & Autumn \\
\hline$\% \mathrm{C}$ & $49.10(0.08)$ & $50.20(0.05)^{*}$ \\
\hline Lignin, $\mu \mathrm{g} \mathrm{mg}^{-1}$ (SE) & $1.77(0.03)$ & $1.86(0.04)^{*}$ \\
\hline $\mathrm{N}, \mathrm{g} \mathrm{kg}^{-1}(\mathrm{SE})$ & $5.43(0.09)$ & $5.55(0.06)$ \\
\hline $\mathrm{P}, \mathrm{g} \mathrm{kg}^{-1}$ (SE) & $0.23(0.01)$ & $0.31(0.01)^{*}$ \\
\hline $\mathrm{K}, \mathrm{g} \mathrm{kg}^{-1}(\mathrm{SE})$ & $1.90(0.06)$ & $3.58(0.14)^{\star}$ \\
\hline $\mathrm{Ca}, \mathrm{g} \mathrm{kg}^{-1}(\mathrm{SE})$ & $9.08(0.18)$ & $7.30(0.24)$ \\
\hline $\mathrm{Mg}, \mathrm{g} \mathrm{kg}^{-1}$ (SE) & $1.65(0.03)$ & $1.69(0.04)$ \\
\hline $\mathrm{S}, \mathrm{g} \mathrm{kg}^{-1}$ (SE) & $0.81(0.029$ & $0.80(0.03)$ \\
\hline $\mathrm{C}: \mathrm{N}$ ratio & $0.91(0.01)$ & $0.91(0.01)$ \\
\hline Lignin:N ratio & $0.33(0.01)$ & $0.34(0.01)$ \\
\hline $\mathrm{Fe}, \mathrm{mg} \mathrm{kg}^{-1}$ (SE) & $79.2(2.85)$ & $89.6(4.18)^{*}$ \\
\hline $\mathrm{Cu}, \mathrm{mg} \mathrm{kg}^{-1}(\mathrm{SE})$ & $4.04(0.09)$ & $3.79(0.17)$ \\
\hline $\mathrm{Zn}, \mathrm{mg} \mathrm{kg}^{-1}(\mathrm{SE})$ & $10.58(0.46)$ & $9.88(0.31)$ \\
\hline $\mathrm{Mn}, \mathrm{mg} \mathrm{kg}^{-1}(\mathrm{SE})$ & $530.75(12.58)$ & $446.33(14.52)^{*}$ \\
\hline $\mathrm{B}, \mathrm{mg} \mathrm{kg}^{-1}$ (SE) & $39.50(1.26)$ & $53.42(0.60)^{*}$ \\
\hline
\end{tabular}

$\mathrm{SE}$ - standard error; $\mathrm{C}$ - carbon; $\mathrm{N}$ - nitrogen; $\mathrm{P}$ - phosphorus; $\mathrm{K}$ - potassium; $\mathrm{Ca}$ - calcium; $\mathrm{Mg}$ - magnesium; $\mathrm{S}$ - sulfur; $\mathrm{Fe}$ - iron; $\mathrm{Cu}$ - copper; $\mathrm{Zn}$ - zinc; $\mathrm{Mn}$ - manganese; B - boron.

*Significant difference between the two seasons according to Tukey's test $(p \leq 0.05)$.

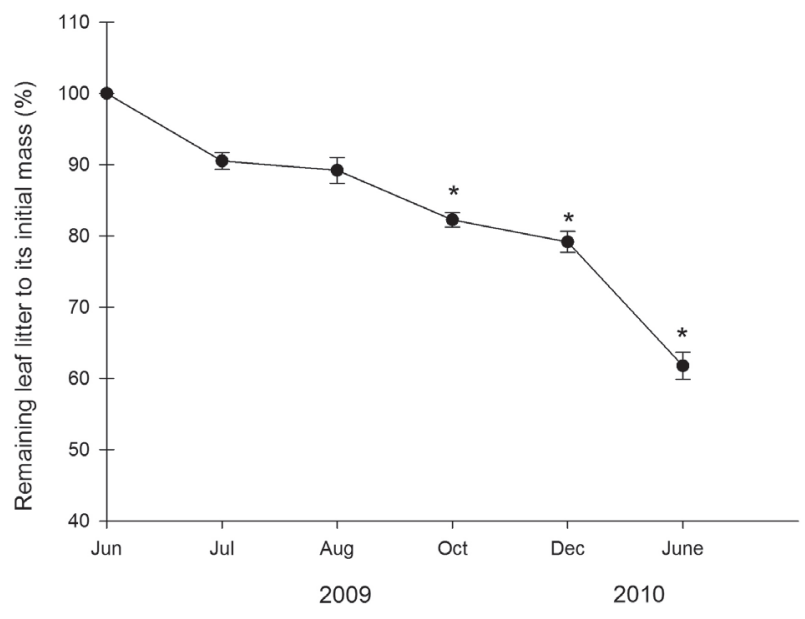

Figure 3. Leaf decomposition rate expressed as the percentage reduction in mass over the course of the one-year study period ( $\Delta \%$ in relation to the baseline values obtained in May 2009) in a commercial plantation of three-year-old individuals of Eucalyptus saligna Labill. (Clone 4039), within the city of Eldorado do Sul, in the state of Rio Grande do Sul, Brazil.

Values represent means with standard errors $(n=10-12 /$ time point).

* Significant difference $(p \leq 0.05)$ in relation to baseline.

\section{Soil carbon accumulation}

The variables selected by the Kruskal-Wallis test were significantly associated with the variations observed in the POC and MAC fractions $(p=0.001$ and $p<0.001$, respectively). Phosphorus, sulfur, zinc and copper concentrations exerted the greatest effects on the particulate carbon concentration at both of the depths evaluated. The variables that best explained the variation observed in the carbon stocks within the MAC fraction were clay content, $\mathrm{pH}$ and copper concentration (Tab. 3). When multiple linear regressions were performed separately for each soil depth, none of the variables tested had any significant effect on the POC and MAC fractions at the $25-50 \mathrm{~cm}$ depth; the only variable that had any such effect at the $0-25 \mathrm{~cm}$ depth was clay content $(p=0.03)$.

None of the chemical characteristics of the leaf litter were associated with the observed variations in the carbon stock in the POC fraction $(p=0.189)$ or in the MAC fraction ( $p=0.872)$ at either of the depths evaluated (Tab. 4). To determine whether such chemical characteristics were associated with the carbon stock in the superficial soil layer, we repeated the linear regression analysis for the POC and MAC fractions at the $0-25 \mathrm{~cm}$ depth. However, that analysis revealed no significant relationships ( $p>0.1$ for all).

\section{Discussion}

The SOM is not homogeneous, being characterized by different fractions that reflect different stages of decomposition of organic residues. The physical fractionation of the SOM allows the mechanisms of protection and stabilization of soil carbon levels to be investigated and proposes a hi- 
Table 3. Results of multiple linear regression between soil characteristics and the soil organic carbon stock in particulate organic carbon and mineral-associated carbon fractions at depths of $\leq 50 \mathrm{~cm}$ in a commercial plantation of three-year-old individuals of Eucalyptus saligna Labill. (Clone 4039), within the city of Eldorado do Sul, in the state of Rio Grande do Sul, Brazil.

\begin{tabular}{lcc}
\hline \multirow{2}{*}{ Soil characteristic } & \multicolumn{2}{c}{ Fraction } \\
\cline { 2 - 3 } Clay content & $\mathrm{POC}^{*}$ & $\mathrm{MAC}^{* *}$ \\
$\mathrm{pH}$ & 0.181 & $0.000^{* * *}$ \\
$\mathrm{P}$ concentration & 0.411 & $0.05^{* * *}$ \\
$\mathrm{~K}$ concentration & $0.037^{* * *}$ & 0.419 \\
$\mathrm{Al}$ concentration & 0.295 & 0.169 \\
$\mathrm{Ca}$ troc concentration & 0.463 & 0.797 \\
$\mathrm{Mg}$ troc concentration & 0.403 & 0.294 \\
$\mathrm{Ca}: \mathrm{Mg}$ ratio & 0.397 & 0.721 \\
$\mathrm{~S}$ concentration & 0.193 & 0.532 \\
$\mathrm{Zn}$ concentration & $0.009^{* * *}$ & 0.463 \\
$\mathrm{Cu}$ concentration & $0.024^{* * *}$ & 0.117 \\
\hline
\end{tabular}

POC - particulate organic carbon; MAC - mineral-associated carbon; P phosphorus; $\mathrm{K}$ - potassium; $\mathrm{Al}$ - Aluminum; $\mathrm{Ca}_{\text {troc }}$ - exchangeable calcium; $\mathrm{Mg}_{\text {troc }}$ - exchangeable magnesium; $\mathrm{S}$ - sulfur; $\mathrm{Zn}$ - zinc; $\mathrm{Cu}$ - copper. ${ }^{*} p=0.001$ for all characteristics.

${ }_{* *}^{*} p<0.001$ for all characteristics.

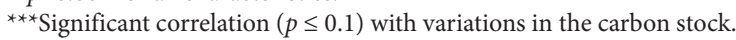

Table 4. Results of multiple linear regression between leaf litter characteristics and the soil organic carbon stock in particulate organic carbon and mineral-associated carbon fractions at depths of $\leq 50 \mathrm{~cm}$ in a commercial plantation of three-year-old individuals of Eucalyptus saligna Labill. (Clone 4039), within the city of Eldorado do Sul, in the state of Rio Grande do Sul, Brazil.

\begin{tabular}{lcc}
\hline Leaf litter characteristic & \multicolumn{2}{c}{ Fraction } \\
\hline N concentration & POC $^{*}$ & MAC $^{* *}$ \\
P concentration & 0.845 & 0.426 \\
K concentration & 0.743 & 0.332 \\
Ca concentration & 0.623 & 0.371 \\
Mg concentration & 0.182 & 0.424 \\
S concentration & 0.289 & 0.202 \\
Cu concentration & 0.62 & 0.751 \\
Zn concentration & 0.535 & 0.302 \\
Fe concentration & 0.503 & 0.637 \\
Mn concentration & 0.72 & 0.264 \\
B concentration & 0.615 & 0.375 \\
Lignin concentration & 0.137 & 0.71 \\
C:N ratio & 0.896 & 0.55 \\
\hline
\end{tabular}

POC - particulate organic carbon; MAC - mineral-associated carbon; $\mathrm{N}$ - nitrogen; $\mathrm{P}$ - phosphorus; $\mathrm{K}$ - potassium; $\mathrm{Ca}$ - calcium; $\mathrm{Mg}$ - magnesium; $\mathrm{S}$ - sulfur; $\mathrm{Cu}$ - copper; $\mathrm{Zn}$ - zinc; $\mathrm{Fe}$ - iron; $\mathrm{Mn}$ - manganese; $\mathrm{B}$ - boron; $\mathrm{C}$ - carbon. ${ }^{*} p=0.189$ for all characteristics.

${ }^{* *} p=0.872$ for all characteristics. erarchical organization of the interactions between carbon and minerals in the soil (Roscoe \& Machado 2002, Mello 2006). In this study, we chose the granulometric method of fractionation to separate the carbon pools of the SOM into the mineral-associated carbon (MAC fractions) and particulate organic carbon (POC fractions).

Our results show that the carbon in the MAC fraction accounted for $\approx 90 \%$ of the TOC, indicating that carbon with more residence time in soil is the main component of the TOC in managed eucalyptus forests. The carbon stock in the POC fraction, characterized by lability and a composition similar to that of vegetable residues in the early stages of decomposition, comprised a much smaller fraction of the TOC $(\approx 10 \%)$.

The soil carbon accumulation in eucalyptus forests does not seem to be directly associated with amount of litter added to the soil (Sausen, 2011). Six et al. (2002) suggested that the physical and chemical characteristics of soil define the capacity for the protection of soil carbon pools, limiting the ability of soil to sequester more carbon, even when the input of organic residues increases. Christensen (1996) and Six et al. (2002) pointed out that SOM accumulation is influenced by chemical characteristics of organic residues and their decomposition process, by the stabilization of organic matter through reactions with mineral surfaces and by the protection of organic residues through training physical barriers.

Our results indicate that certain chemical and physical variables have a positive relationship with the soil carbon stock in both SOM fractions. Of the variables tested, clay content, copper concentration and $\mathrm{pH}$ were significantly associated with the variation in the MAC fraction, whereas phosphorus, sulfur, copper and zinc concentrations were responsible for the variation in the POC fraction.

The stabilization of SOM involves the association of organic matter with clay and silt particles, represented by the carbon stock in the MAC fraction. In fact, our results indicate a positive relationship between the clay content and the MAC fraction, confirming the characteristic of this fraction to represent a stable carbon pool, strongly adsorbed to soil mineral surfaces. The observed relationship between copper concentration and the MAC fraction might be associated with the role of metal cations in the stabilization of the SOM (Alloway 1990), whereas the soil pH seems to influence the cation exchange capacity between the soil solution and the SOM (Canellas et al. 2008). Schjønning et al. (1999) and Thomsen et al. (1999) suggested that the mechanisms of aggregation between the organic matter and mineral particles to form organo-mineral complexes are associated with the physical properties of the soil, such as soil texture and $\mathrm{pH}$, and the processes that affect microbial activity. That is in agreement with the results obtained in the present study, mainly that the positive relationship between clay content and the carbon stock in the MAC fraction is related to the mechanisms of soil carbon sequestration. 
The POC fraction is considered a labile carbon pool, characterized by the transition between the litter carbon and the mineral-associated organic matter (Christensen 2001). The fact that we found phosphorus and sulfur concentrations to be related to the POC fraction might be attributable to the release of nutrients through leaching during the initial phase of litter decomposition. The release of phosphorus from the litter of Eucalyptus globulus is related to the reduction in mass during decomposition (Madeira et al. 2007), and the leaching of soluble sulfates contributes significantly to the release of sulfur from the litter (Homann et al. 1991). In addition, the relationship between phosphorus and sulfur in the POC fraction might be associated with the release of amino acids during decomposition (Poirier et al. 2005). One limitation of the present study is that we did not analyze the chemical composition of the leaf litter throughout the decomposition process. Therefore, we cannot infer that the release of nutrients through litter decomposition is responsible for the concentrations of phosphorus and sulfur showing positive relationships with the carbon stock in the POC fraction. Furthermore, the positive relationship observed for the nutrients phosphorus, sulfur, copper and zinc might be associated with the important roles that these nutrients play in plant physiology, rather than with their roles in the processes of aggregation and stabilization of the SOM.

Six et al. (2001) and Poirier et al. (2005) found that the chemical composition of different soil fractions was determined predominantly by plant material, differing only in the nature of organic compounds according to the soil fraction analyzed. In the present study, we found that none of the chemical characteristics of the leaf litter fraction showed a significant relationship with the POC or MAC fraction. We believed that the lignin concentration in the litter would be associated with carbon stock, especially in the MAC fraction, because of its recalcitrance. However, neither the lignin concentration nor the lignin:nitrogen ratio was associated with changes in the soil carbon stock. It is likely that our period of evaluation (12 months) was too short, which prevent us from detecting relationships between recalcitrant residues in the leaf litter and soil carbon accumulation.

In eucalyptus plantations, the leaf litter usually decays more slowly and accumulates in the soil in greater proportion than in native tropical forests (O'Connell \& Sankaran 1997). Aerts \& Chapin (2000) postulated that within a particular climate zone, the parameters related to the chemical composition of the litter exert greater control over the decomposition process, and the lignin:nitrogen ratio is considered the best indicator of decomposability. The lignin concentration and lignin:nitrogen ratio can be used as indicators of the decomposition of organic residues in the eucalyptus forest, although not as measures of the variations in soil carbon accumulation. The decay constant observed here for Eucalyptus saligna plantations under a subtropical climate (0.49) was similar to those observed for plantations of E. grandis in Argentina (Goya et al. 2008); of E. globulus in
Portugal (Madeira et al. 2007); and of E. dives and E. rubida in Australia (Crockford \& Richardson 2002).

Our results indicate that carbon accumulation in a weathered subtropical Ultisol is mainly associated with the reactions of organic matter stabilization through the interaction of organic matter with clay particles and, to a lesser extent, with metal ions. It is also of note that, in that same soil, the intrinsic characteristics of the soil had a greater impact on carbon accumulation than did the decomposition of organic residues or the chemical characteristics of the leaf litter.

\section{Acknowledgments}

The authors are grateful to the researcher Elias Frank Araújo, for assisting in the field experiments. This study received financial support from Celulose Riograndense, a subsidiary of the Chilean Compañia Manufacturera de Papeles y Cartones (CMPC, Pulp and Paper Manufacturing Company) and from the Brazilian Coordenação de Aperfeiçoamento de Pessoal de Nivel Superior (CAPES, Office for the Advancement of Higher Education; doctoral scholarship to TLS).

\section{References}

Aerts, R. \& Chapin, FS III. 2000. The Mineral Nutrition of Wild Plants Revisited: a re-evaluation of process and patterns. Advances in Ecological Research 30: 1-67.

Alloway, B.J. 1990. The origins of heavy metals in soils. Pp. 29-39. In: Alloway, B.J. (Ed.). Heavy metals in soils. New York, John Wiley.

Bayer, C.; Martin-Neto, L.; Mielniczuk, J. \& Pavinato, A. 2004. Armazenamento de carbono em frações lábeis da matéria orgânica de um Latossolo Vermelho sob plantio direto. Pesquisa Agropecuária Brasileira 39: 677-683.

Berg, B. \& McClaugherty, C.A. 2008. Plant Litter: Decomposition, Humus Formation, Carbon Sequestration. Berlin, Springer Verlag Heidelberg.

Berg, B.; Berg, M.B.; Bottner, P.; Box, E.; Breymeyer, A.; Calvo de Anta, R.; Couteaux, M.; Escudero, A.; Gallardo, A.; Kratz, W.; Madeira, M.; Malkonen, E.; McClaugherty, C.; Meentemeyer. V.; Muñoz, F.; Piussi, P.; Remacle, J. \& Virzo de Santo, A. 1993. Litter mass loss rates in pine forests of Europe and Eastern United States: some relationships with climate and litter quality. Biogeochemistry 20: 127-159.

Cambardella, C.A. \& Elliot, E.T. 1992. Particulate soil organic matter change across a grassland cultivation sequence. Soil Science Society of America Journal 56: 777-783.

Canellas, L.P.; Mendonça, E.S.; Bobbss, L.B.; Baldotto, M.A.; Velloso, A.C.X.; Santos, G.A.; \& Amaral Sobrinho, N.M.B. 2008. Reações da Matéria orgânica. Pp. 45-64. In: Santos, G.A.; Silva, L.; Canellas, L.P. \& Camargo, F.A.O. (Eds.). Fundamentos da matéria orgânica do solo: ecossistemas tropicais e subtropicais. Porto Alegre, Metrópole.

Christensen, B.T. 1996. Carbon in primary and secondary organo-mineral complexes. Pp. 97-165. In: Carter, M.R. \& Stewart, B.A. (Eds). Advances in Soil Science - Structure and Organic Matter Storage in Agricultural Soils. Boca Raton, CRC Lewis Publishers.

Christensen, B.T. 2001. Physical fractionation of soil and structural and functional complexity in organic matter turnover. European Journal of Soil Science 52: 345-353.

Clough, A. \& Skjemstad, J.O. 2000. Physical and chemical protection of soil organic carbon in three agricultural soils with different contents of cal- 
cium carbonate. Australian Journal of Soil Research 38: 1005-1016.

Crockford, R.H. \& Richardson, D.P. 2002. Decomposition of litter in a dry sclerophyll eucalypt forest and a Pinus radiata plantation in southeastern Australia. Hydrological Process 16: 3317-3327.

Ferrarese, M.L.L.; Zottis, A. \& Ferrarese-Filho, O. 2002. Protein-free lignin quantification in soybean (Glycine max) roots. Biologia 57:541-543.

Fog, K. 1988. The effect of added nitrogen on the rate of decomposition of organic matter. Biology Reviews 63: 433-462.

Goya, J.F.; Frangi, J.L.; Pérez, C.; \& Tea, F.D. 2008. Decomposition and nutrient release from leaf litter in Eucalyptus grandis plantations on three different soils in Entre Ríos, Argentina. Bosque 29: 217-226.

Hobbie, S.E. 2000. Interactions between Litter Lignin and Soil Nitrogen Availability during Leaf Litter Decomposition in a Hawaiian Montane Forest. Ecosystems 3: 484-494.

Homann, P.S. \& Cole, D.W. 1990. Sulfur dynamics in decomposing forest litter: Relationship to initial concentration, ambient sulfate and nitrogen. Soil Biology and Biochemistry 22: 621-628.

Kleber, M.; Sollins, P. \& Sutton, R. 2007. A conceptual model of organomineral interactions in soils: self-assembly of organic molecular fragments into zonal structures on mineral surfaces. Biogeochemistry 85: 9-24.

Kögel-Knabner, I. 2002. The macromolecular organic composition of plant and microbial residues as inputs to soil organic matter. Soil Biology and Biochemistry 34: 139-162.

Lützow, M.V.; Kögel-Knaber, I.; Ekschmitt, K.; Matzner, E.; Guggenberger, B.; Marschner, B. \& Flessa, H. 2006. Stabilization of organic matter in temperate soils: mechanisms and their relevance under different soil conditions - a review. European Journal of Soil Science 57: 426-445.

Madeira, M.; Cortez, N.; Azevedo, A.; Magalhães, M.C.; Ribeiro, C. \& Fabião, A. 2007. As plantações de eucalipto e o solo. Pp. 137-174. In: Alves, A.M.; Pereira, J.S.; \& Silva, J.M.N. (Eds). O Eucaliptal em Portugal: Impactos Ambientais e Investigação Científica. Lisboa, ISA Press.

Mello, N.A. 2006. Efeito do Sistema de Manejo nos Atributos do solo, Movimentação de Sedimentos e Exportação de Carbono Orgânico numa Microbacia Rural sob Cultura do Fumo. Tese de Doutorado. Porto Alegre, Universidade Federal do Rio Grande do Sul.
Morris, S.J.; Bohm, S.; Hale-Mariam, S. \& Paul, E.A. 2007. Evaluation of carbon accrual in afforested agricultural soils. Global Change Biology 13: 1145-1156.

O'Connell, A.M. \& Sankaran, K.V. 1997. Organic Matter Accreation, Decomposition and Mineralization. Pp. 443-480. In: Nambiar, E.K.S. \& Brown, A.G. (Eds). Management of Soil, Nutrients and Water in Tropical Plantation Forests. Canberra, Australian Centre for International Agricultural Research.

Olson, J.S. 1963. Energy storage and the balance of producers in ecological systems. Ecology 44: 322-331

Pauletto, E.A. 1997. Manual de Laboratório: determinação de atributos físicos do solo. Pelotas, Universidade Federal de Pelotas.

Poirier, N.; Sohi, S.P.; Gaunt, J.L.; Mahieu, N.; Randall, E.W.; Powlson, D.S. \& Evershed, R.P. 2005. The chemical composition of measurable soil organic matter pools. Organic Geochemistry 36: 1174-1189.

Roscoe, R. \& Machado, P.L.O.A. 2002. Fracionamento físico do solo em estudos da matéria orgânica. Dourados, Embrapa Agropecuária Oeste.

Sausen, T.L. 2011. Dinâmica e estoque de carbono em plantios subtropicais de Eucalyptus saligna e mediterrâneos de Eucalyptus globulus. Tese de Doutorado. Porto Alegre, Universidade Federal do Rio Grande do Sul.

Schjønning, P.; Thomsen, I.K.; Moberg, J.P.; de Jonge, H.; Kristensen, K. \& Christensen, B.T. 1999. Turnover of organic matter in differently textured soils. I. Physical characteristics of structurally disturbed and intact soils. Geoderma 89: 177-189.

Six, J.; Conant, R.T.; Paul, A. \& Paustian, K. 2002. Stabilization mechanisms of soil organic matter: Implications for C-saturation of soils. Plant and Soil 241: 155-176.

Six, J.; Guggenberger, G.; Paustian, K.; Haumaier, L.; Elliot, E.T. \& Zech, W. 2001. Sources and composition of soil organic matter fractions between and within soil aggregates. European Journal of Soil Science 52: 607-618

Tedesco, M.J.; Gianello, C.; Bissani, C.A.; Bohnen, H. \& Volkweiss, S.J. 1995. Análises do solo, plantas e outros materiais. Porto Alegre, Universidade Federal do Rio Grande do Sul.

Thomsen, I.K.; Schjønning, P.; Jensen, P. \& Christensen, B.T. 1999. Turnover of organic matter in differently texture soils. II. Microbial activity as influenced by soil water regimes. Geoderma 89: 199-218 